\title{
Structural Interpretation and Petrophysical Analysis for Reservoir Sand of Lower Goru, Miano Area, Central Indus Basin, Pakistan
}

\section{Muhammad Sohail Khan 1*, Farhana Masood ${ }^{2}$, Qadeer Ahmed ${ }^{3}$, Ishtiaq Ahmed Khan Jadoon 4 , Naveed Akram ${ }^{1}$}

\author{
${ }^{1}$ School of Earth and Space Sciences, University of Science and Technology of China, Hefei, China \\ ${ }^{2}$ Quaid-i-Azam University, Islamabad, Pakistan \\ ${ }^{3}$ Oil and Gas Development Company Limited, Islamabad, Pakistan \\ ${ }^{4}$ COMSATS Institute of Information Technology, Abbottabad, Pakistan \\ Email: *sohailabbottabad@yahoo.com
}

How to cite this paper: Khan, M.S., Masood, F., Ahmed, Q., Jadoon, I.A.K. and Akram, N. (2017) Structural Interpretation and Petrophysical Analysis for Reservoir Sand of Lower Goru, Miano Area, Central Indus Basin, Pakistan. International Journal of Geosciences, 8, 379-392.

https://doi.org/10.4236/ijg.2017.84020

Received: June 21, 2016

Accepted: April 10, 2017

Published: April 14, 2017

Copyright () 2017 by authors and Scientific Research Publishing Inc. This work is licensed under the Creative Commons Attribution International License (CC BY 4.0).

http://creativecommons.org/licenses/by/4.0/

\begin{abstract}
The main purpose of this research is to estimate the structural analysis and hydrocarbon potential of Miano Block by using seismic and well log techniques. Miano area hosts a number of gas fields with structural and stratigraphic traps. The area is located in Central Indus Basin which is a part of an extensional regime exhibiting normal faulting due to the split of the Indian Plate firstly from Africa and then from Madagascar and Seychelles. Miano area recognized as a proven petroleum province which has complex tectonic history of Cretaceous extensional and overprints of Tertiary strike-slip tectonics. The area has prospect with accumulation of hydrocarbons in structural and stratigraphic traps including pinchouts. NW-SE oriented Khairpur and Mari Highs are main structural features with impact on the fault system. The sands of Lower Goru of Lower Cretaceous age are acting as a reservoir in the area. The area has great potential of hydrocarbons for which more exploratory wells are required to be drilled with better insight of structural and stratigraphic traps.
\end{abstract}

\section{Keywords}

Seismic Interpretation, Time-and-Depth Contour Map, 3D View, Synthetic Seismograph, Reservoir Estimation

\section{Introduction}

Miano area is located 62 kilometers southeast of Sukkur city in Thar Desert as shown in Figure 1 [1] which is geographically located in the Sindh province of 
Pakistan between longitudes $69^{\circ} 12^{\prime} \mathrm{E}$ and $69^{\circ} 28^{\prime} \mathrm{E}$ and latitude $27^{\circ} 14^{\prime} \mathrm{N}$ and $27^{\circ} 32^{\prime} \mathrm{N}$ respectively. The vast sedimentary basins cover about $80 \%$ of the total country's area with widespread oil and gas seepages. Despite the long history of oil and gas exploration and an attractive petroleum policy, the sedimentary basins still contain sizeable areas, classified as frontiers, which cover more than $60 \%$ of the total prospective area including the Pishin Basin, the Maluan-I Charan Basin,

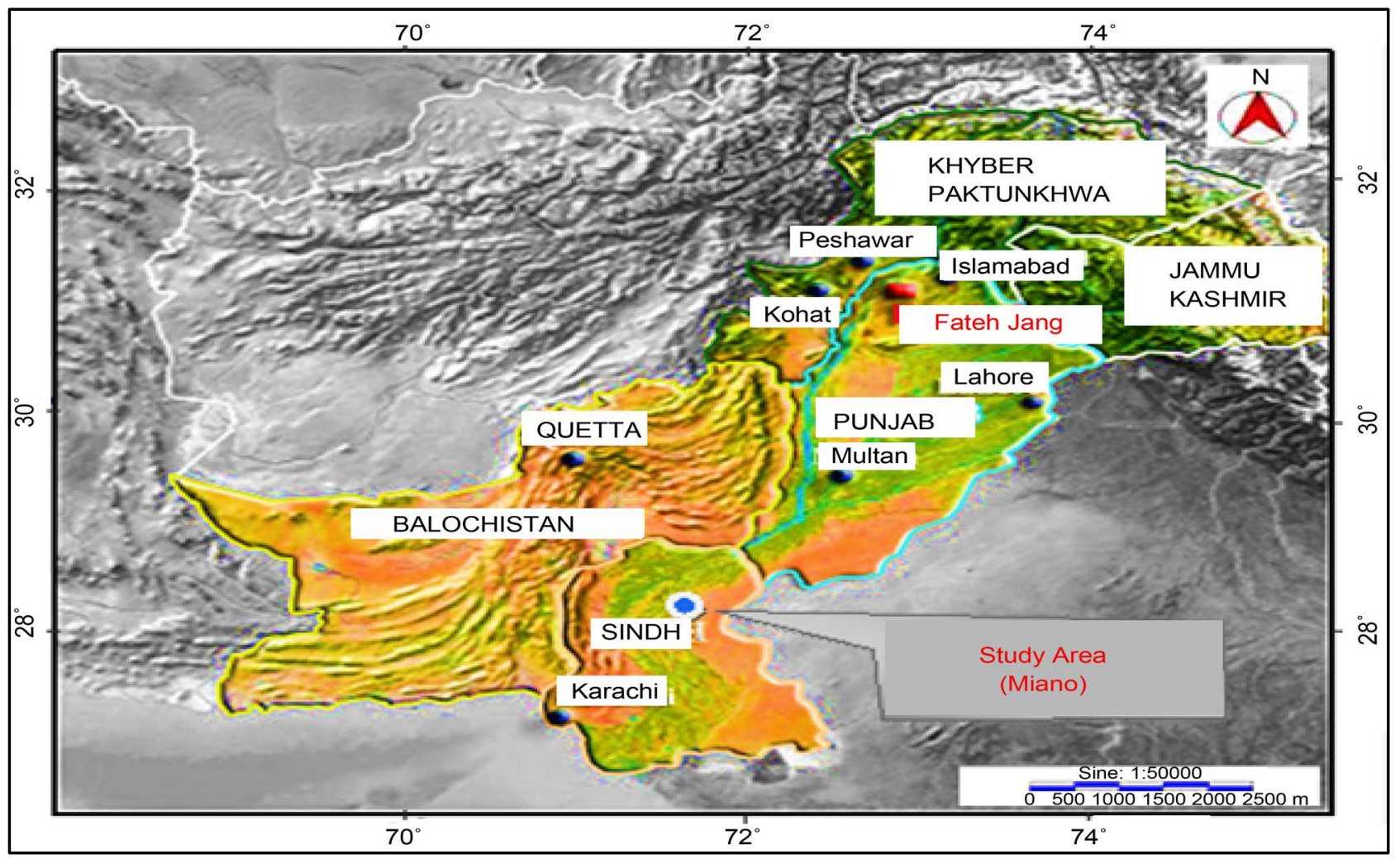

Figure 1. Representing the location of the area (Naqi and Siddiqui, 2006).

Fold and Thrust Belt parts of the Platform of the Indus Basin and the entire Offshore [2] [3]. Geologically it is located in Central Indus about 421 exploratory wells have been dug all across Pakistan. In the Southern Indus Basin 55 exploratory wells were drilled during the period 1955-1984, but 27 of these wells based on the results of multifold seismic surveys [4]. In the past hundreds of years of petroleum research, compared to an average of one hundred wells in other similar basins, Pakistan remained one of the least explored basins of which the well density is less than five per 10,000 sq. Kms. The country desperately needs to exploit new oil and gas potentials across the new frontiers to increases self-reliance. For sustainable exploration, more efforts should be directed towards these frontier areas which after exploration may prove to be of greatest potential [5]. The Miano is located in the Middle Indus Basin and it is dominated with cretaceous extensional fault with trend NNW to SSE direction [6]. This paper briefly highlights the depositional framework of the reservoir present at deep level along with geology and stratigraphy of the basin in which study area is present. But it requires a commitment from both the oil companies and the gov- 
ernment to achieve success. New plays concepts need to be utilized with new technology along with advanced geological and geophysical studies that highlight the potential of these areas. This study analyzes this area in order to describe the potentialities of this basin which has emerged in the past few years as a major gas province due to many major gas discoveries along with many other discoveries in Pakistan. A variety of depositional and structural regimes are associated with this region.

\section{Geological Background and Stratigraphy of the Area}

The Miano is located in the Middle Indus Basin, Pakistan to the south of Suleiman and east of Kirthar fold belt Figure 2 [7] and it is dominated with Cretaceous extensional fault system with trend in NNW to SSE direction, these features are obliterated with Tertiary strike-slip faults [8]. Due to interaction of extensional and strike-slip faults complex of structures is interpreted with segmentation of Cretaceous clastic reservoirs in the area. Extensional faulting is attributed to the rifting and northward drifting of the Indian plate from Gondwanaland. Whereas, strike-slip faults may have developed due to docking of the Indian plate with the Eurasian plate about $55 \mathrm{Ma}$ and subsequent anticlockwise rotation [9].

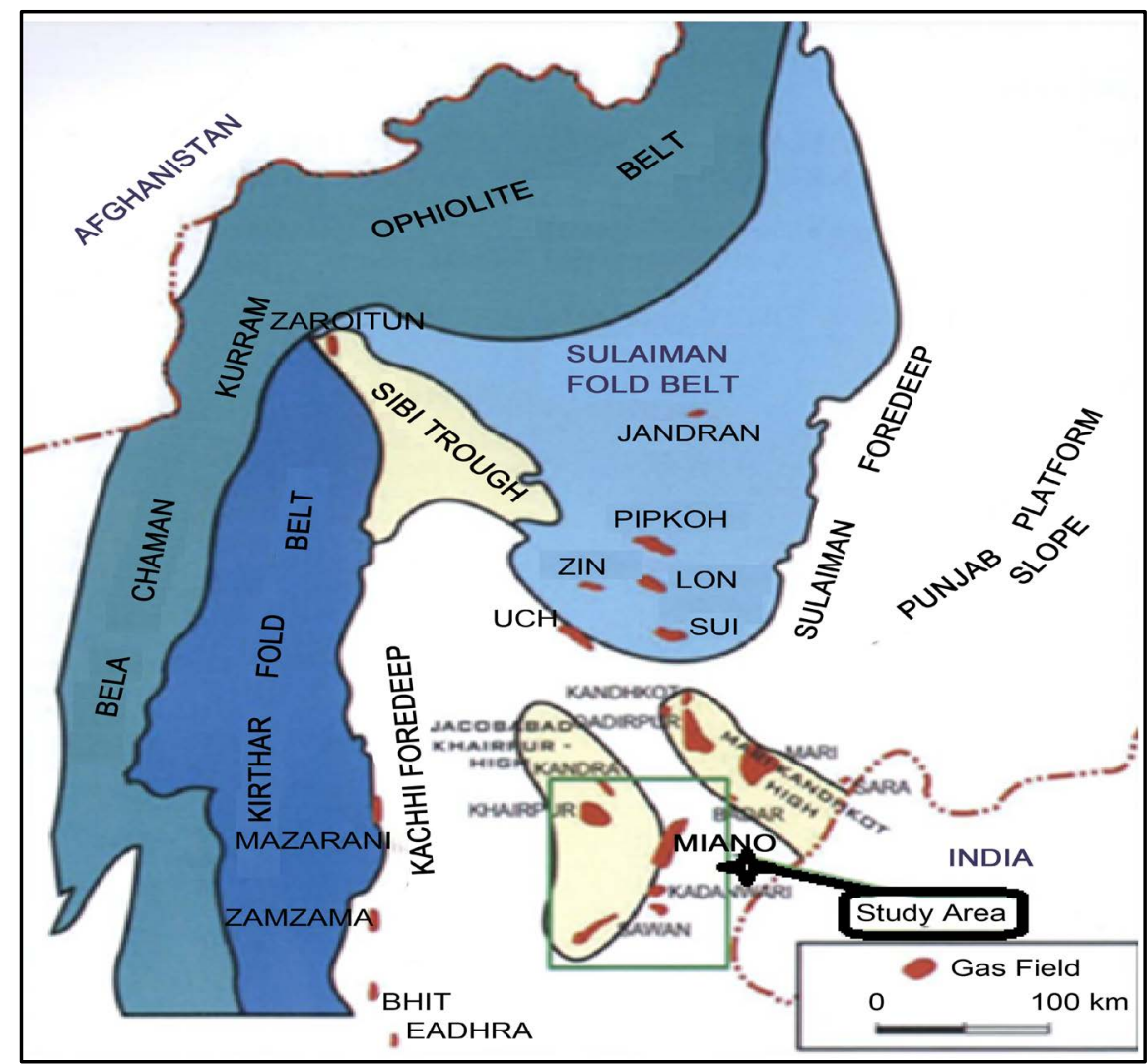

Figure 2. Representing map of the central indus basin of the study area (Krois et al., 1998).

Study area in Middle Indus basin comprises mainly of Permian to Mesozoic sediments over an unconformity of late Paleozoic stage. High has been active 
since Jurassic and Paleocene strata are absent along the crust and adjacent region. Whole region of study is heavily covered by alluvium deposits no out crops are available at the surface, which can yield a straight signal of the stratigraphic successionas shown in Figure 3. Reservoir rocks in that area are lower, upper Goru and Parh formations. Depositional environment of the Lower Goru " $\mathrm{B}$ " is interpreted to be a tide dominated lithology of sandstone. In the study areasands is the major producing reservoir. The color of Sandstone is yellowish brown and dirtywhite. Small acoustic impedance of seismic waves together with strong seismic amplitudes shows the presence of reservoir quality sands.

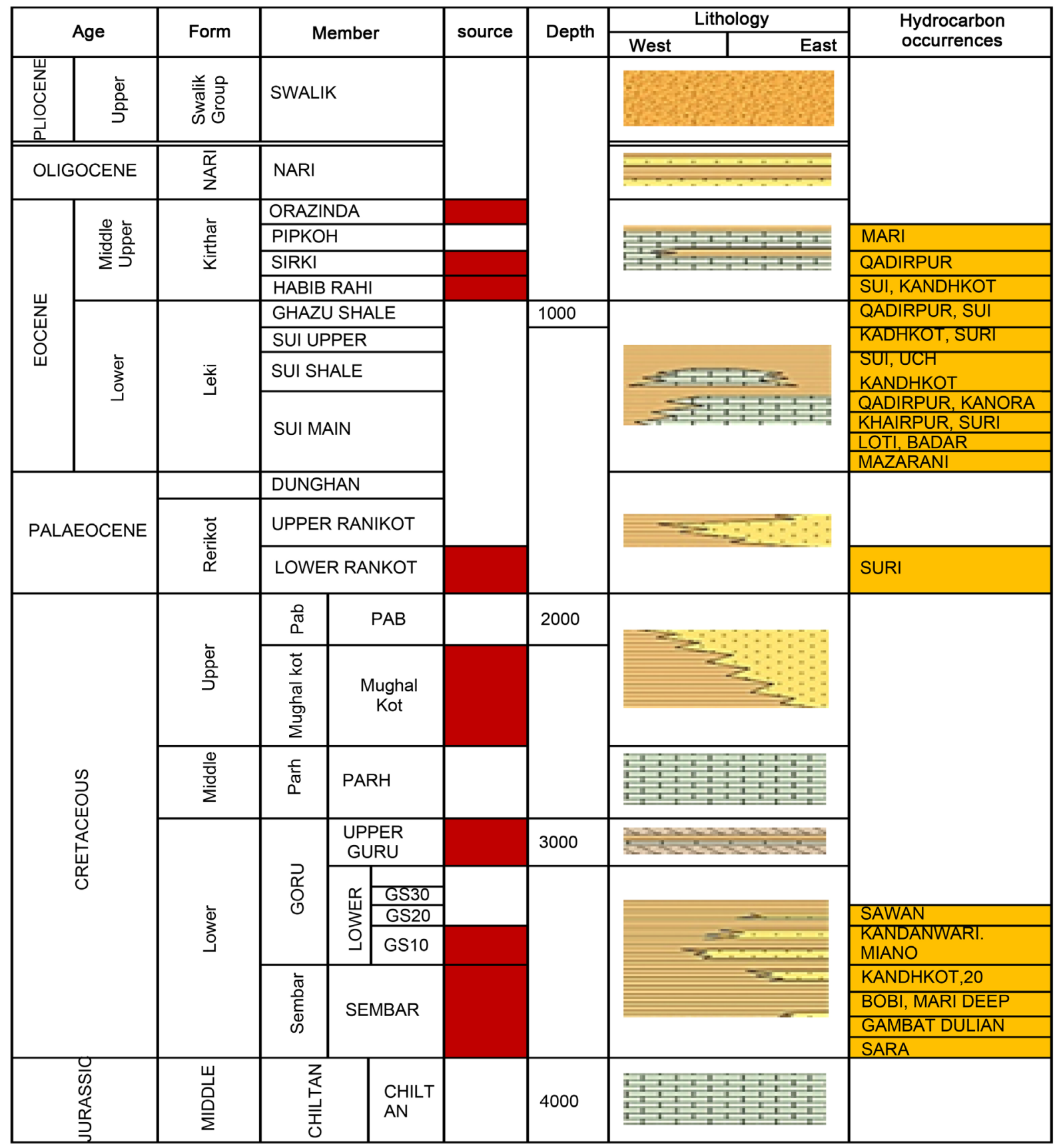

Figure 3. [10] Representing the stratigraphy of thecentral Indus Basin (ENI, Pakistan). 


\section{Data and Methodology}

Data for this research was acquired as part of a project to reassess the oil and gas exploration potential through a regional potential field data survey of the area and a seismic data survey in the Central Indus Platform basin area of Pakistan. To achieve the desired objective we used given methodologies.

- Interpretation of seismic lines.

- Subsurface mapping and structural interpretation of the study area using Seismic and Well data.

- Time-and-depth contour map.

- 3D view.

- Synthetic Seismograph

- Reservoir characterization.

\section{Interpretation of the Potential Field Data}

Seismic data has been analyzed and interpreted to understand sedimentation and structure for a geological model Figure $4 \&$ Figure 5 . Firstly horizons mapping has been done with their marking on all the seismic lines.seismic data linked with well Top data and known geology of area [11], Sirki shale (light green), Habib Rahi (Orange), Sui main limestone (Pink), Ranikot (Red), Upper Goru (Yellow), Lower Goru (Orange), Lower Goru sand (Dark blue), Chiltan (Cyan). EW trending lines are dip lines. The NS trending lines are strike lines. Faults are clearly visible on dip lines but on strike lines they are not clearly observed. The fault tie points from dip lines were highlighted on the strike lines. Numbers of normal faults are marked on the seismic lines which represent are extensional regime. The interpreted seismic lines P2092-111 and P2092-113 are dip lines with clear interpretation of the above mentioned horizons. The time of horizons within Cretaceous stratigraphy increases from west to east due to thickness variation indicating direction of sediment deposition in the area from west to east. Several high-angle faults are marked on the seismic lines. Some of them occur as a set with dip towards east or west bounding graben structures. 

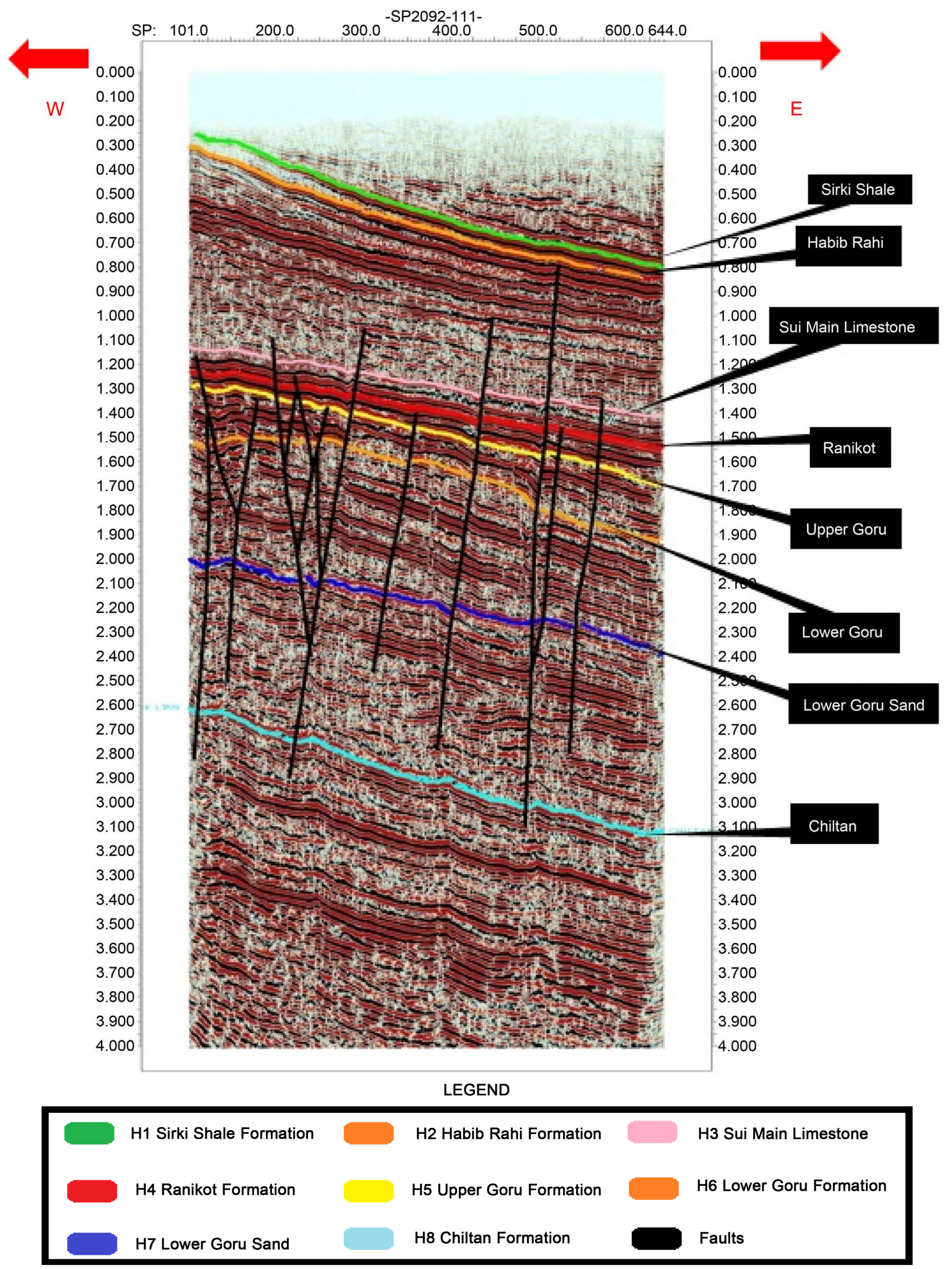

Figure 4. Interpreted seismic section line P2092-111. 


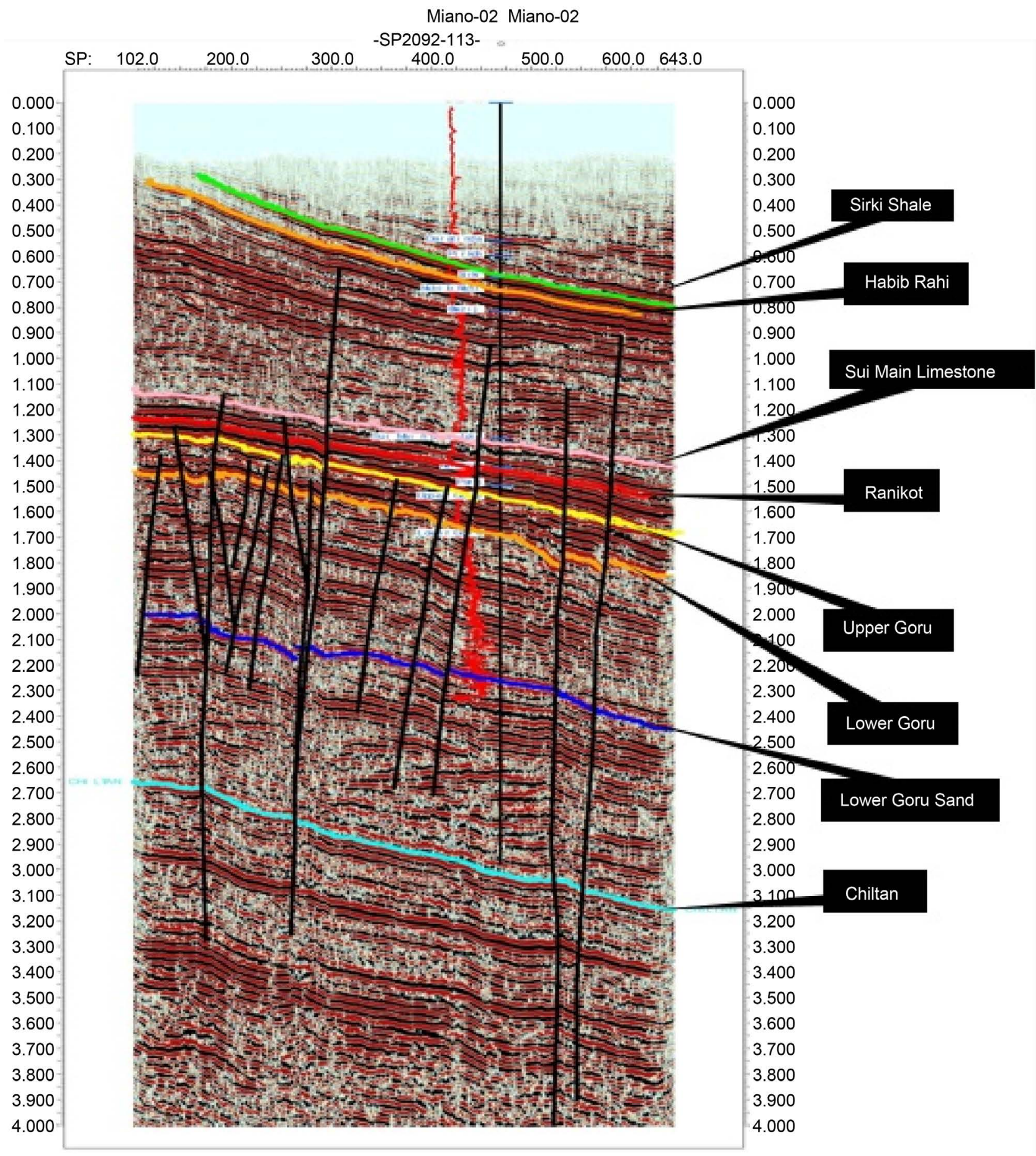

LEGEND

H1 Sirki Shale Formation

H4 Ranikot Formation

H7 Lower Goru Sand
H2 Habib Rahi Formation

H5 Upper Goru Formation

H8 Chiltan Formation
H3 Sui Main Limestone

H6 Lower Goru Formation

Faults

Figure 5. Interpretation of seismic lines P2092-113. 


\section{Time Contour Map of Lower Goru Formation}

Time contours map of Lower Goru Formation clearly shows in Figure 6 \& Figure 7. A set of east dipping faults with exception of one that dips to the west. The faults are sub vertical and planner. Geometry of fault bounded blocks resembles book-shelf modeling of an extensional system with anticlockwise rotation of each blockand presence of a major graben between two faults in the eastern part of the study area. As horst and grabens are formed in the area so tectonically the area lies in extensional regime. Contour shows the formation is shallow towards west, which clearly indicates the sediments transport from west to east during Cretaceous in the area of study.

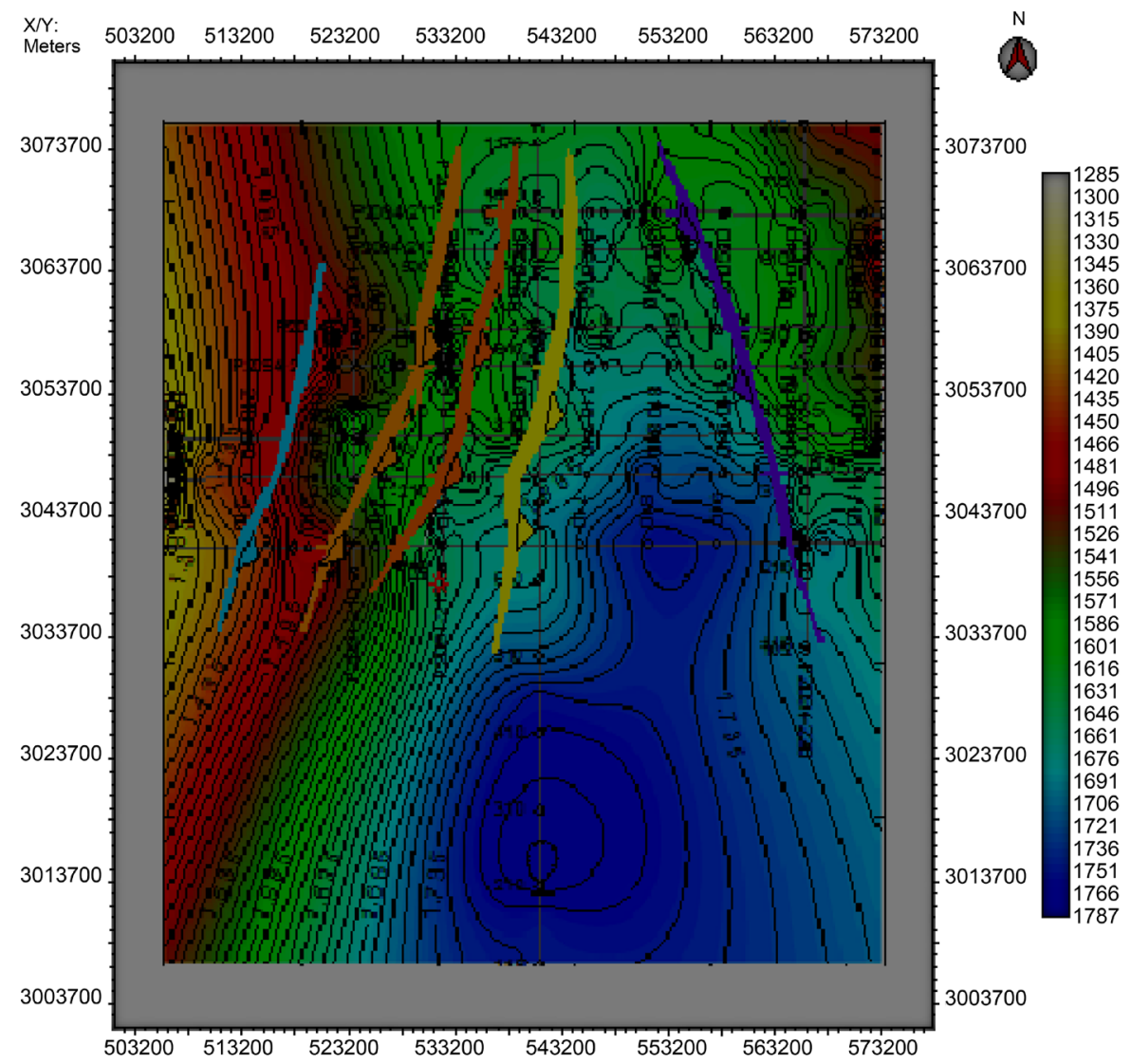

Figure 6. Time contour map of Lower Goru Formation. 


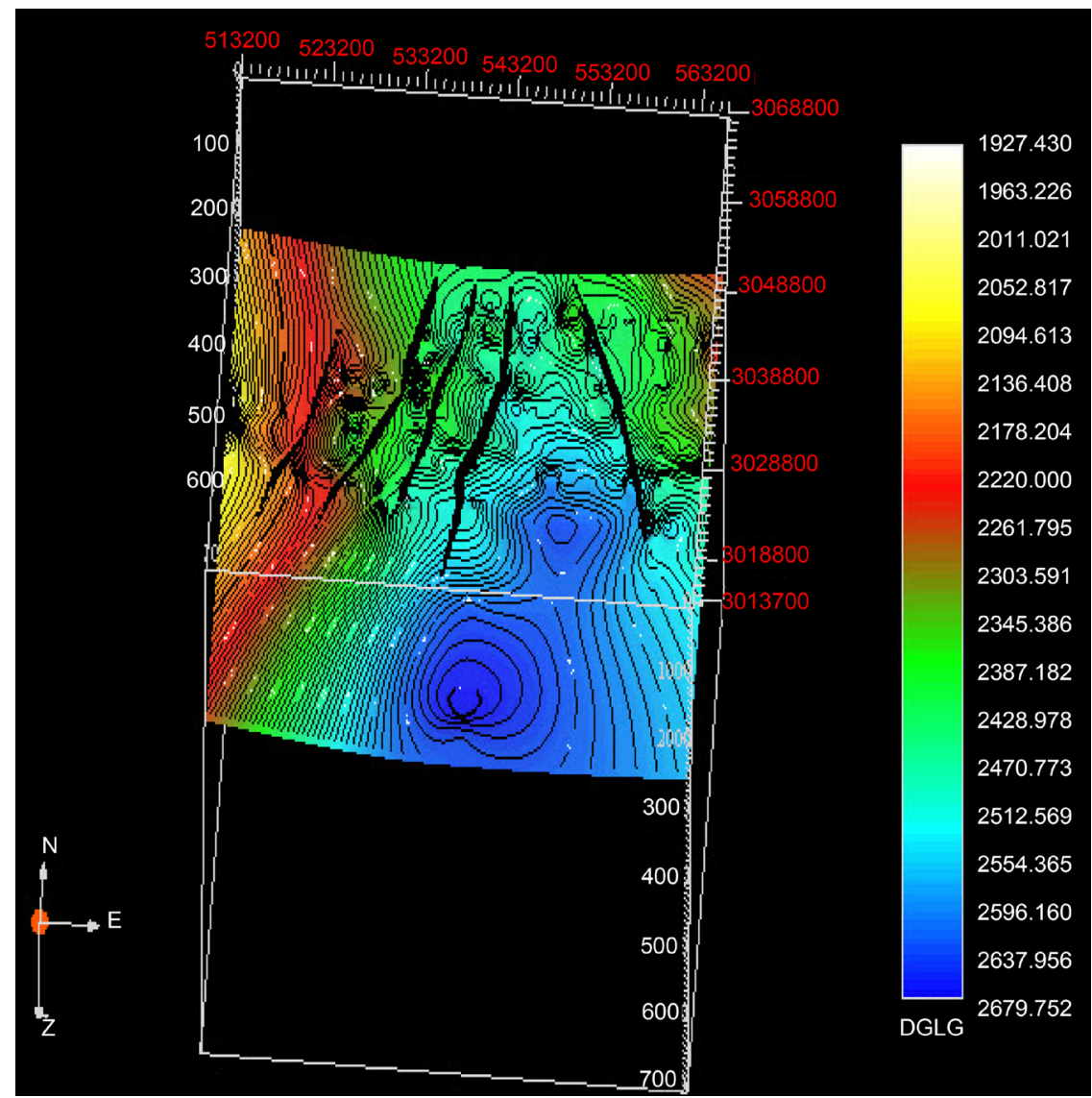

Figure 7. 3D view of Lower Goru Formation.

\section{Depth Contour Map of Lower Goru Formation}

Depth contour maps more clearly depict the subsurface structures. The depths can be calculated from time maps by using velocity of the horizons from the sonic or velocity functions of data. Depth of Lower Goru Formation Ranges from 2000 to 2400 meters. Depth maps indicates that the depth of horizons increases from west to direction with presence of a conspicuous depression (graben) in the study area, similar to as seen in through the time contour map Figure 8 \& Figure 9. 


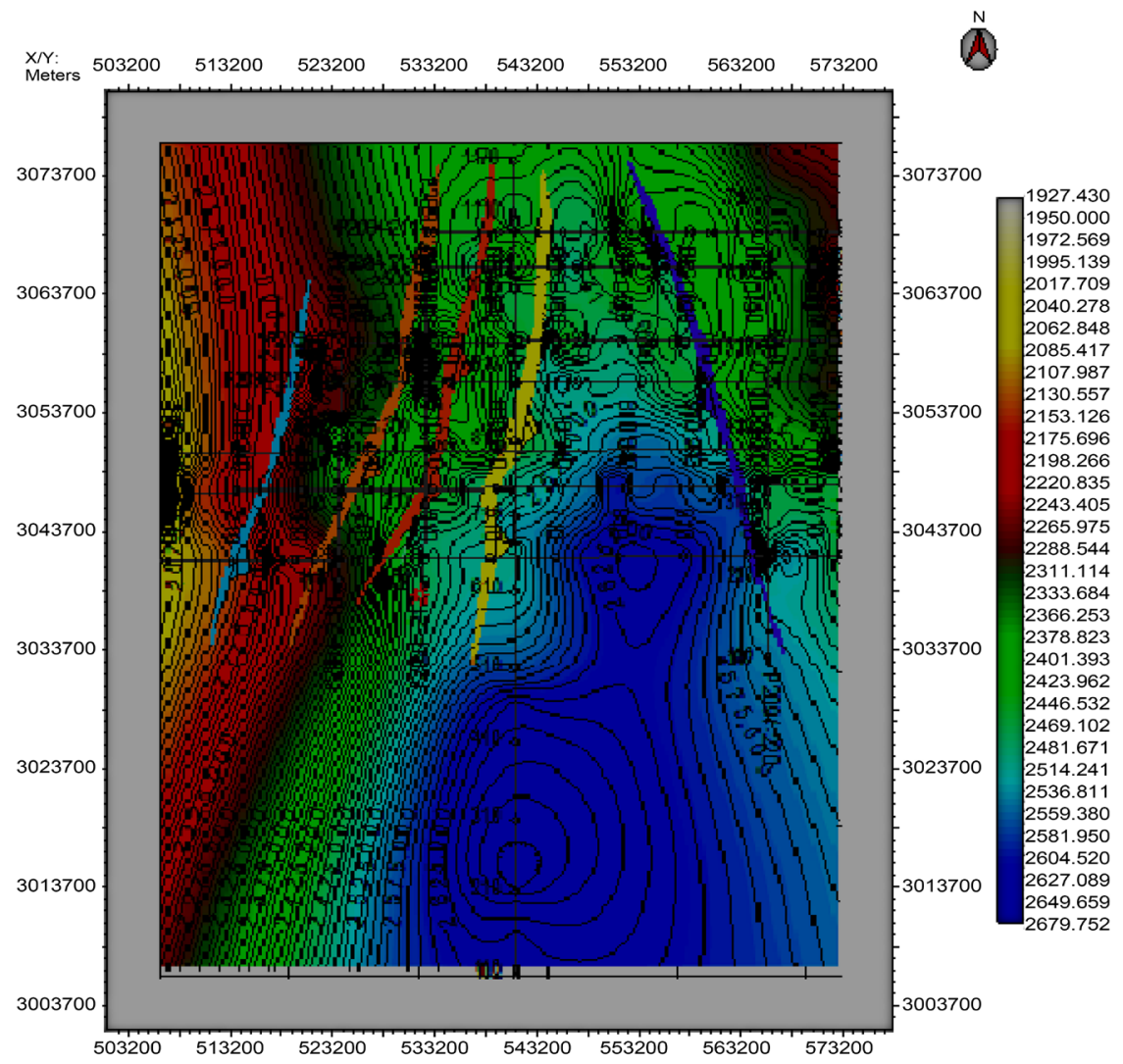

Figure 8. Depth map of Lower Goru Formation.

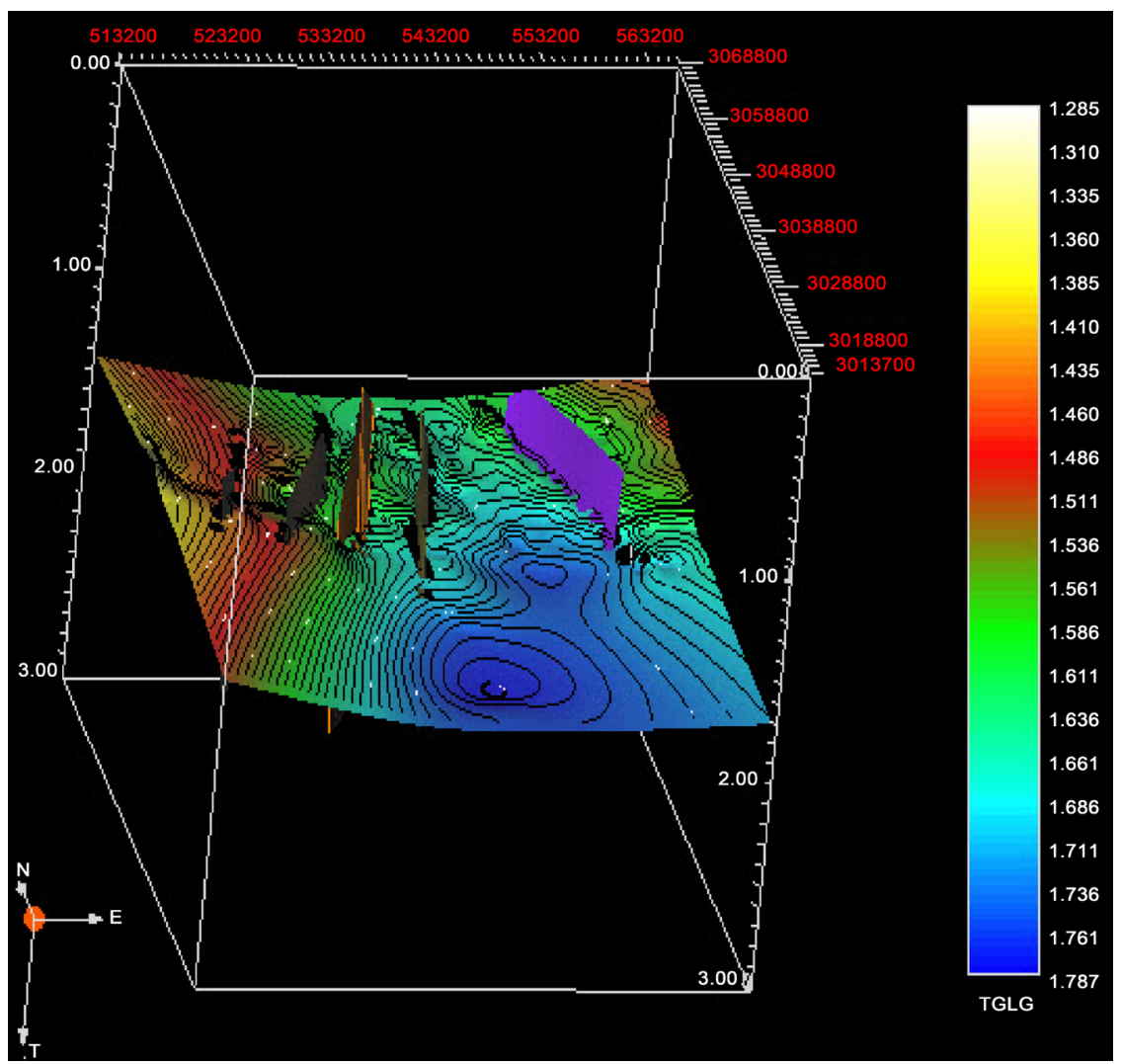

Figure 9. 3D surface map of Lower Goru Formation. 


\section{Seismic Synthetic Modeling}

Synthetic seismogram holds very important information like ground level, time scale, sample interval datum. Synthetic seismograph has been generated based on logs in Miano-02 well Figure 10. Synthetic seismogram has the information of phase data used and length of wavelet generated with the depth scale based on sonic log, density logs, and reflection coefficient log.

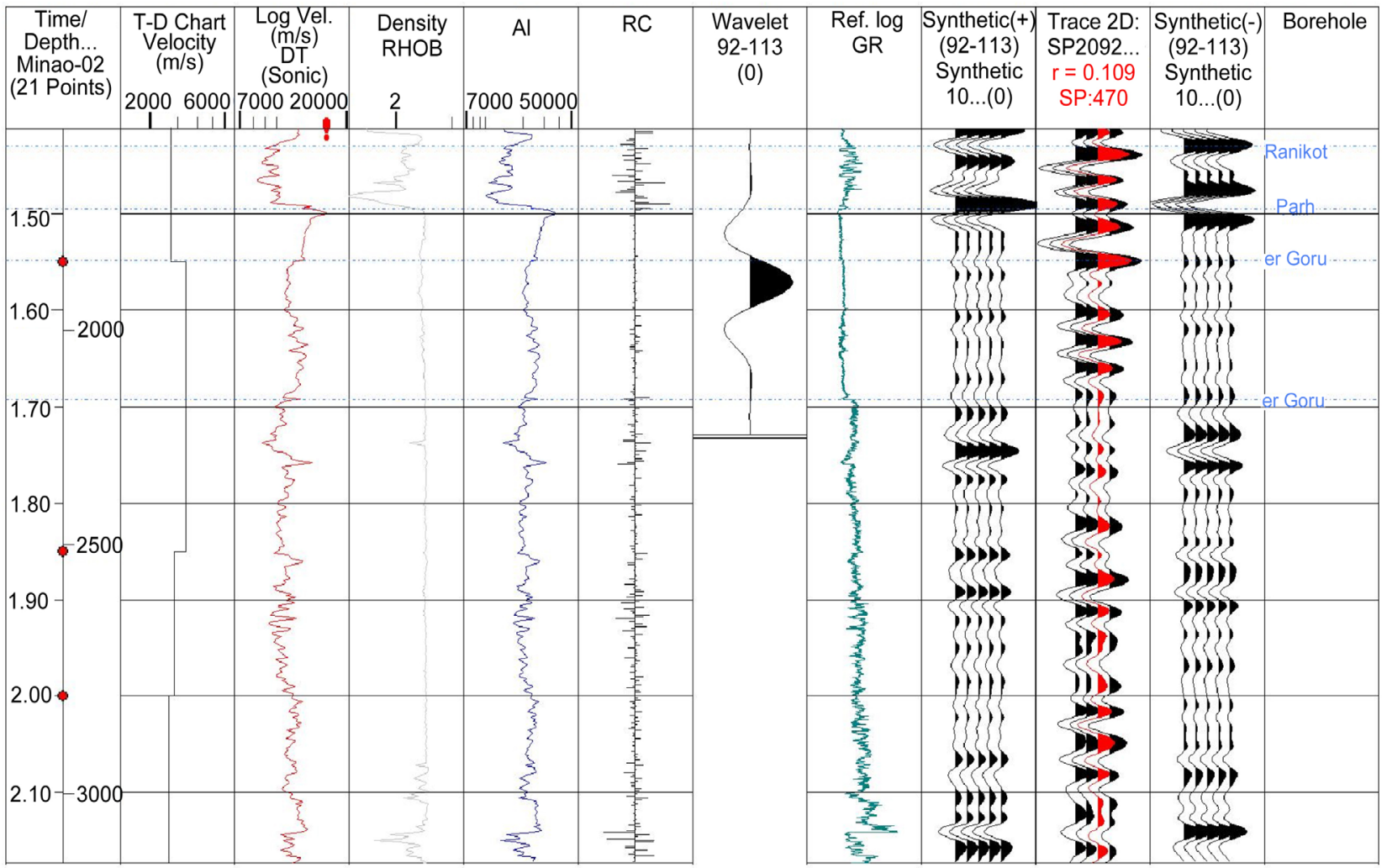

FORMATIONDEPTH DEPTH AVG VEL TIME TO TIME INT VEL THICKNESS

(Elev. Re(TTVDSeis) TOP THICKNESS

$\begin{array}{lllllll}0.0 & -63.5 & -1 . \$ & 0.00000 & 0.54272 & 1842.6 & 500.0\end{array}$

$\begin{array}{lllllll}500.0 & 436.5 & 1608.6 & 0.54272 & 0.54272 & 1842.6 & 500.0 \\ 567.0 & 503.2 & 1670.8 & 0.60050 & 0.05784 & 2316.7 & 67.0\end{array}$

$\begin{array}{llllllll}567.0 & 503.2 & 1676.8 & 0.60056 & 0.05784 & 2316.7 & 67.0 \\ 671.0 & 607.5 & 1778.8 & 0.68304 & 0.08248 & 2521.8 & 104.0\end{array}$

$\begin{array}{llllllll}671.0 & 607.5 & 1778.8 & 0.68304 & 0.08248 & 2521.8 & 104.0 \\ 740.0 & 676.5 & 1841.7 & 0.73465 & 0.05161 & 2673.7 & 69.0\end{array}$

$\begin{array}{llllllll}864.0 & 800.5 & 1956.1 & 0.81847 & 0.08382 & 2958.7 & 124.0\end{array}$

$\begin{array}{lllllll}1483.0 & 1419.5 & 2157.6 & 131579 & 0.49732 & 2489.4 & 619.0\end{array}$

$\begin{array}{llllllll}16760 & 1612.5 & 2256.5 & 1.42922 & 0.11343 & 3403.0 & 193.0\end{array}$

$\begin{array}{lllllll}1799.0 & 1735.5 & 2322.4 & 1.49455 & 0.06533 & 3765.5 & 123.0\end{array}$

$\begin{array}{lllllll}1899.0 & 1835.5 & 23720 & 154766 & 0.05311 & 3765.5 & 100.0\end{array}$

$\begin{array}{lllllll}2226.0 & 2162.5 & 2554.5 & 1.69308 & 0.14541 & 4497.5 & 327.0\end{array}$

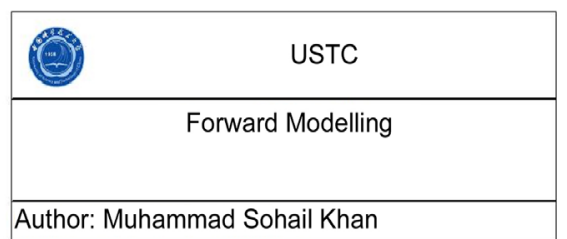

Figure 10. Synthetic seismograph based on logs in Miano-02 well.

\section{Petrophysical Analysis}

Hydrocarbon reservoirs are characterized with the help of mud logging and wire line log data of Miano-02 have been selected for reservoir characterization in this study Figure 11 \& Figure 12. Mud logging is a direct method to interpret the subsurface lithology like the outcrop. The penetration rate of the drilling bit into the formation may be compared to a sonic or gamma ray log, a good interpretation of bed boundaries can be made from these logs. 
M. S. Khan et al.

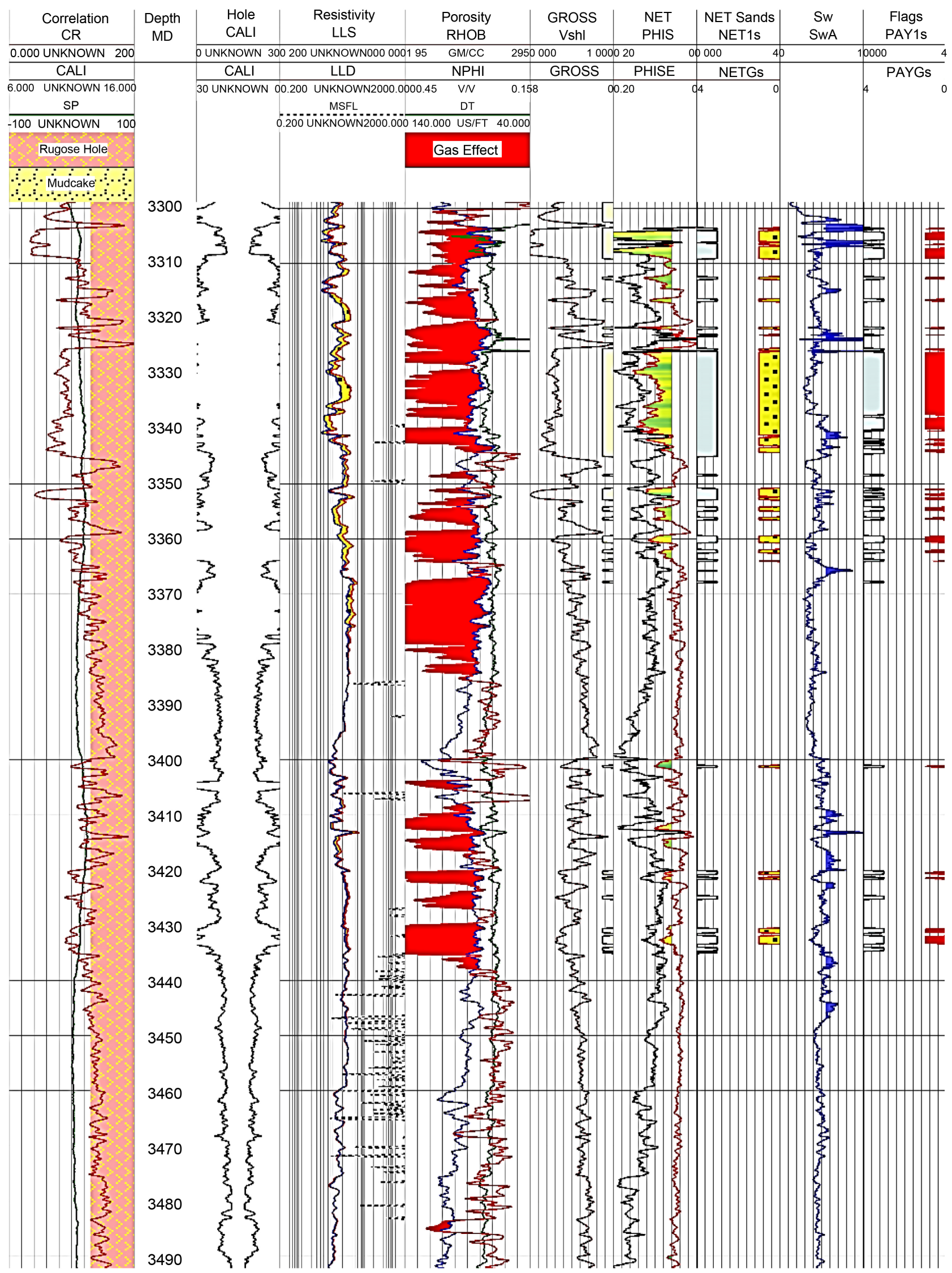

Figure 11. Petrophysical analysis of Miano-02 B Sand. 
M. S. Khan et al.

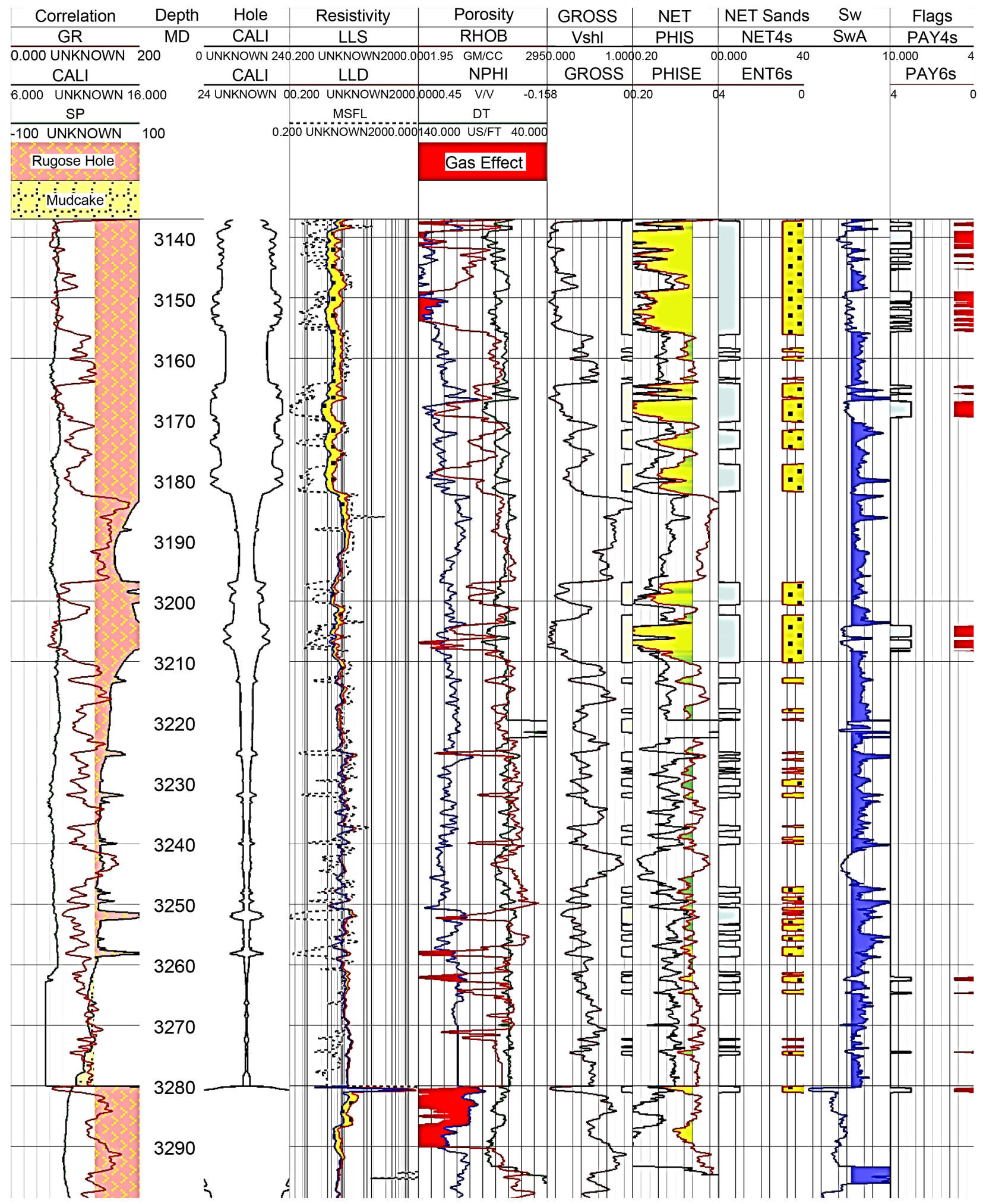

Figure 12. Petrophysical analysis of Miano-02C Sand. 


\section{Conclusion}

The study results shows that the whole area is bounded by structural and stratigraphic traps. Complex tectonic history has made it a good prospect area and accumulation of hydrocarbons is due to structural, lithological variation and pinching of strata. Since a suitable environment is required for hydrocarbon to develop. Reason for having major discoveries is the presence of kitchen area between them. The porosity values varying between $18 \%-22 \%$ are ideal for reservoir sand in Central Indus Basin. The study depicts that Miano prospect area has a great potential of hydrocarbons and more exploratory wells may be drilled in the future targeting the Lower Goru Sands.

\section{Acknowledgements}

This research is supported by Anhui Provincial Government, China and Higher education Commission, Pakistan. We thanks Prof. Dr. Huajian Yao, University of Science and Technology of China (USTC) and constructive comments by anonymous reviewers, which helped us to improve the manuscript. We would like to thanks DGPC \& LMKR Pakistan for providing us oil \& gas industry data for this research.

\section{References}

[1] Naqi, A. and Siddiqui, Z. (2006) Systematic GIS Development and Its Successful Implementation in SSGC. ESRI International GIS User Conference, San Diego, 7-11 August 2006, 1-22.

[2] Raza, H.A. and Ahmed, R. (1990) Hydrocarbon Potential of Pakistan. Journal of Canada Pakistan Cooperation, 4, 9-27.

[3] Raza, H.A. (1997) Exploration Strategy for Frontier Regions of Pakistan. 1 st Annual Technical Convention of PAPG, Islamabad, 26-27 September 1997.

[4] Quadri, V. and Shuaib, S.M. (1986) Hydrocarbon Prospects of Southern Indus Basin, Pakistan. AAPG Bulletin, 70, 730-747.

[5] Bowles, E.G. (1997) Under Explored Basins of Pakistan, an Oil Company's Perspective. 1 st Annual Technical Convention of PAPG, Islamabad, 26-27 September 1997.

[6] Khan, et al. (2013) Integrated Geophysical Study of the Lower Indus Platform Basin Area of Pakistan. International Journal of Geoscience, 4, 1242-1247. https://doi.org/10.4236/ijg.2013.49118

[7] Krois, P., Mahmood, T. and Milan, G. (1998) Miano Field, Pakistan, a Case History of Model Driven Exploration. Pakistan Petroleum Convention, Islamabad, 25-26 November 1998.

[8] Ahmed, et al. (2013) Mesozoic Structural Architecture of the Middle Indus Basin Pakistan-Control and Implications. PAPG-SPE Annual Technical Conference, Islamabad, 26-27 November 2013.

[9] Powell, C.M., et al. (1979) Spectacular Tectonic History of Pakistan and Its Surrounding: Some Constraints from the Indian Ocean. In: Dejong, K. and Farah, A., Eds., Geodynamics of Pakistan, Geological Survey of Pakistan, Quetta, 5-24.

[10] Represent Stratigraphy of Central Indus Basin ENI Pakistan.

[11] Dobrin, M.B. and Savit, C.H. (1998) Introduction to Geophysical Prospecting. 4th Edition, McGraw Hill, New York. 
Submit or recommend next manuscript to SCIRP and we will provide best service for you:

Accepting pre-submission inquiries through Email, Facebook, LinkedIn, Twitter, etc. A wide selection of journals (inclusive of 9 subjects, more than 200 journals)

Providing 24-hour high-quality service

User-friendly online submission system

Fair and swift peer-review system

Efficient typesetting and proofreading procedure

Display of the result of downloads and visits, as well as the number of cited articles Maximum dissemination of your research work

Submit your manuscript at: http://papersubmission.scirp.org/

Or contact ijg@scirp.org 